PREGLEDNI RAD - REVIEW

\title{
Voće i povrće kao biokatalizatori za dobivanje kiralnih spojeva
}

\section{Fruits and vegetables as biocatalysts for chiral compounds synthesis}

\section{Karla Hanousek Čiča ${ }^{*}$, Jasna Mrvčić ${ }^{1}$, Damir Stanzer ${ }^{1}$, Tamara Jakovljevićć, Ivana Radojčić Redovniković1}

\author{
${ }^{1}$ Prehrambeno-biotehnološki fakultet, Sveučilište u Zagrebu, Pierottijeva 6, 10000 Zagreb \\ ${ }^{2}$ Hrvatski šumarski institut, Cvjetno naselje 41, 10450 Jastrebarsko \\ *Corresponding author: khanousekcica@pbf.hr
}

Sažetak

Zbog bolje učinkovitosti i sigurnosti potreba za enantiomerno čistim kiralnim spojevima u stalnom je porastu, pogotovo u farmaceutskoj industriji. Da bi se te potrebe zadovoljile potrebne su nove, učinkovitije i jeftinije ali i ekološki prihvatljive metode njihove priprave. U skladu s tim veliku je pažnju privukla biokataliza gdje se kao biokatalizatori koriste mikroorganizmi ili enzimi izolirani iz njih. Posljednjih godina znanstvena zajednica se okrenula istraživanju upotrebe svježeg, netaknutog biljnog materijala kao biokatalizatora. Upotreba biljnog materijala ne zahtijeva dodatak skupih kofaktora budući da se različiti enzimski sustavi i potrebni kofaktori, te njihov regeneracijski sustav već nalaze u biljnom tkivu. Ovisno o upotrijebljenoj biljci (voću, povrću, začinima), pojedini enantiomeri se mogu dobiti u visokom prinosu is visokim enantiomernim viškom, što je kritični faktor za razvoj biološki aktivnih spojeva i njihovu bioaktivnost. U ovom radu dan je pregled istraživanja potencijalne upotrebe različitih biljnih vrsta i njihovih dijelova kao biokatalizatora u stereoselektivnim transformacijama pogodnih spojeva s ciljem dobivanja novih enentiomerno čistih spojeva. Primjena biljnih biokatalitičkih sustava u skladu je s principima zelene kemije i predstavlja značajnu alternativu sintetskim kemijskim postupcima.

Ključne riječi: kiralni spojevi, biokataliza, voće, povrće, enantiomerni višak

Abstract

Due to better efficiency and safety the need for enantiomerically pure chiral compounds is increasing, especially in the pharmaceutical industry. To meet these needs, new, more efficient and cheaper but also environmental-friendly methods of their preparation are needed. Accordingly, great attention has been drawn to biocatalysts in which microorganisms or theirs enzymes are used as biocatalysts. Recently, the scientific community turned to research on the use of fresh, intact plant material as a biocatalyst. The use of plant material does not require the addition of expensive cofactors since various enzyme systems and necessary cofactors, and their regeneration system already exists in plant tissue. Depending on the plant used (fruits, vegetables, spices), either enantiomers may be obtained in high yield and with high enantiomeric excess, which is a critical factor for the development of biologically active compounds and their bioactivity. In this paper, various studies of different plant species parts as biocatalysts in stereoselective transformations of compounds to obtain enantiomerically pure chiral compounds are presented. The use of plants as a biocatalytic systems is in accordance with green chemistry principles and represents a significant alternative to synthetic chemical transformations that would meet the needs of ecological and economic.

Keywords: chiral compounds, biocatalysis, fruits, vegetables, enantiomeric excess

\section{Uvod}

Kiralni spojevi su spojevi koji se zbog nesimetričnog prostornog rasporeda atoma ne mogu poklopiti sa svojom zrcalnom slikom. Enantiomerima se naziva par kiralnih molekula koje se odnose kao predmet i zrcalna slika, a smjesa dvaju enantiomera u molarnom omjeru 1:1 racemičnom smjesom. Enantiomerna čistoća kiralnog spoja izražava se kao enantiomerni višak (engl. enantiomeric excess, ee) i predstavlja omjer razlike i sume mo- larnih udjela enantiomera u smjesi dvaju enantiomera (Faber, 2004). Interakcije kiralnih spojeva s kiralnom okolinom kao što su biološki sustavi mogu rezultirati biološki različitim te ponekad suprotnim učinkom enantiomera. Tako na primjer jedan enantiomer nekog kiralnog spoja može imati ljekovito djelovanje dok drugi enantiomer toksično djelovanje. Dugotrajnom i skupom klasičnom, organskom sintezom u pravilu nastaje racemična smjesa nekog kiralnog spoja (enantiomerni par), dok upotrebom biokatalizatora jedan enantiomer nastaje u suvišku u 
odnosu na drugi. Zbog sigurnosnih, terapeutskih i regulatornih razloga enantiomerna čistoća biološki aktivnih kiralnih spojeva je od velike važnosti, posebice u farmaceutskoj industriji (Camacho-Munoz i sur., 2016; Rouf i Taneja, 2014).U skladu s tim, potreba za enantiomerno čistim kiralnim spojevima u stalnom je porastu te zahtjeva razvoj i primjenu novih i učinkovitijih metoda priprave.

Nadalje, u organskoj sintezi postoji stalan trend za primjenom zelenih procesa koji ne narušavaju ekološku i ekonomsku ravnotežu već se temelje na principima zelene kemije. Poseban naglasak stavljen je na biotransformacije tj. transformacije tvari kemijskog ili biološkog podrijetla primjenom enzima ili cijelih stanica. Prednosti upotrebe cijelih stanica ili izoliranih enzima kao biokatalizatora u odnosu na konvencionalne kemijske katalizatore su specifičnost za supstrat, enantioselektivnost, blagi reakcijski uvjeti ( $\mathrm{pH}$ i temperatura), višekratna upotreba, te ekološka prihvatljivost (Schmid i sur., 2001). Navedene prednosti upotrebe biokatalizatora uz uštedu sirovina, energije i vremena rezultirale su implementacijom različitih biokatalitičkih procesa, posebice za sintezu kiralnih spojeva u farmaceutskoj, kemijskoj, prehrambenoj industriji i industriji agrokemikalija (Wandrey i sur., 2000). Različite vrste biokatalizatora učinkovito kataliziraju sintezu različitih kemijskih spojeva. Najčešće se kao biokatalizatori koriste mikroorganizmi - plijesni, kvasci i bakterije ili enzimi izolirani iz njih. Upotrebi biljaka kao biokatalizatora posvećeno je manje pažnje. U usporedbi $\mathrm{s}$ mikroorganizmima, biljke imaju složenije metaboličke puteve koji su daleko slabije istraženi, a kada se u obzir uzme broj otkrivenih i neotkrivenih biljnih vrsta raste i potencijal njihove upotrebe. Istraživanja biljaka kao biokatalizatora u reakcijama transformacije rezultirala su trima različitim sustavima za modifikaciju supstrata: kultura biljnih stanica, enzimi izolirani iz biljaka i čitav/svježi/netaknuti biljni materijal. Osnovni pristup sastoji se od brze i ekonomične sintetske modifikacije određene funkcijske skupine uz jednostavnu manipulaciju. Ove modifikacije uključuju, u većini slučajeva, redukciju prokiralnih ketona ili dvostrukih veza, hidrolizu estera, konverziju alkohola u halogenide, oksidaciju alkohola i esterifikaciju (Da Silva i sur., 2017). Reinhard i Alfermann (1980) dali su vrlo zanimljiv pregled biotransformacija supstrata u kulturi biljnih stanica, s posebnim naglaskom na aromatske spojeve, kumarine, alkaloide, terpenoide i steroide.

Prepoznavši poteškoće vezane uz korištenje kultura biljnih stanica, Baldassare i suradnici 2000. godine bili su jedna od prvih znanstvenih skupina koji su za provođenje biotransformacija organskih supstrata koristili svježi biljni materijal, bez ikakve obrade. Nasjeckanom korijenu mrkve (Daucus carota) dodan je supstrat u omjeru 1:200. Nakon $50 \mathrm{~h}$ racemična smjesa 2-metilcikloheksanona reducirana je u $(1 S, 2 R)$ i $(1 S, 2 S)$ alkohol s $>99$ $\%$ enantiomernog viška (ee). Ova studija potaknula je istraživanja upotrebe svježeg, netaknutog biljnog materijala kao reagensa umjesto kulture stanica te suspendiranih ili imobiliziranih, izoliranih biljnih enzima. Prednost upotrebe biljnog materijala kao biokatalizatora je što nije potrebno dodavati skupe kofaktore budući da se različiti enzimski sustavi, kofaktori te njihov regeneracijski sustav već nalaze u biljnom tkivu (Yang i sur., 2008; Chang i sur., 2010). Nadalje, upotreba usitnjenog biljnog materijala u biotransformacijama moguća je i zbog enzima koji se izlučuju u reakcijski medij te mogu modificirati ksenobiotičke supstrate (Mączka i Mironowicz, 2002). Biotransformacijski postupak je vrlo jednostavan zbog velike dostupnosti biljaka, blagih reakcijskih uvjeta i upotrebe vode umjesto otapala, čak i za slabo topljive spojeve, bez dodatka izvora ugljika (što je potrebno prilikom korištenja mikroorganizma) i kofakora (što je potrebno prilikom korištenja izoliranih enzima) (Bruni i sur., 2002; Yang i sur., 2008). Ovisno o upotrijebljenoj biljci (voću, povrću, začinima), pojedini enantiomeri se mogu dobiti u visokom prinosu i visokom enantiomernom višku, što bi mogao biti ključni čimbenik za razvoj lijekova i njihovu biološku aktivnost. Međutim, uobičajeni problem koji se javlja kod korištenja biljaka kao biokatalizatora je mikrobna kontaminacija (Fruchey, 2011). Naime, mikroorganizmi mogu biti uključeni u proces bioredukcije iako se biljke koriste kao primaran izvor enzima (Matsuda i sur., 2009). Zbog širokog biotehnološkog potencijala enzimskih reakcija, biotransformacije pomoću biljaka mogu se primijeniti u fitoremedijaciji organskih zagađivača, bioredukciji ketona, enzimskoj laktonizaciji, adiciji cijanovodika i hidroksilaciji, hidrolizi estera te oksido-redukcijskim reakcijama (Andrade i sur., 2006).

\section{Asimetrična redukcija prokiralnih aldehida i ketona u kiralne alkohole pomoću voća i povrća}

Biokatalitička redukcija aldehida i ketona jedna je od najvažnijih, temeljnih i praktičnih reakcija za dobivanje kiralnih alkohola, intermedijera u proizvodnjibiološki aktivnih spojeva kao što su lijekovi, agrokemikalije, arome i mirisi, feromoni, itd. (Matsuda i sur., 2009; Javidnia i sur., 2016). Nekoliko alkohola smatra se ključnim polaznim supstratima u sintezi mirisnih tvari za kozmetičku industriju i industriju aroma. Iako su u literaturi opisani različiti postupci za proizvodnju alkohola sintetskim postupcima, biokataliza predstavlja važan alat u organskoj sintezi za pripremu ishodišnih alkohola za sintezu mirisnih tvari. Najznačajniji alkoholi su fenilmetanol, 4-hidroksimetil-2-metoksifenol, 1,3-benzodioksol-5-metanol, 4-metoksifenil metanol, 2-furilmetanol, 3-fenilprop-2-en-1-ol i 1-feniletanol. U literaturi postoje brojni primjeri bioredukcije prokiralnih ketona u kiralne alkohole primjenom kultura biljnih stanica no mogućnost izravnog korištenja dijelova biljaka kao biokatalizatora istražuje se tek posljednih 20 godina (tablica 1). Prije 2000. godine, fokus je bio na mikroorganizmima kao biokatalizatorima. Zbog brojnih prednosti kao što su sposobnost rasta $\mathrm{u}$ anaerobnim uvjetima, dobre tolerancije na niske $\mathrm{pH}$ vrijednosti, veće koncentracije šećera i etanola uz nisku cijenu, veliku dostupnost i netoksičnost pekarski kvasac (Saccharomyces cerevisiae) korišten je kao biokatalizator u reakcijama biodehidrogenacije, hidrolize, oksidacije, te najčešće u redukciji prokiralnih ketona (Chin-Joe i sur., 2000; Santaniello i sur., 2000; Fardelone i sur., 2004; Nevoigt, 2008). Upotrebu pekarskog kvasca kao svestranog biotransformacijskog alata u organskoj sintezi ograničili su niski prinosi i niska enantiomerna čistoća produkta zbog različite stereospecifičnosti reduktaza prisutnih u kvascu te slabe topljivosti organskih supstrata u vodenom mediju (Khor i Uzir, 2011). Od 2000. godine uobičajena biljka koja se više puta upotrebljava kao biokatalizator za stereoselektivnu redukciju mnogih ketona je mrkva, dok su acetofenonski derivati najčešće ispitivani/modelni supstrati upotrijebljeni za enantioselektivnu bioredukciju u odgovarajuće kiralne alkohole budući da mogu dati oba enantiomera (Rodrigues i sur., 2004 i 2007). 
Tablica 1. Pregled istraženih biljaka za bioredukciju određenih supstrata (Patil, 2015)

Table 1. Plant material used for bioreduction of different substrates (Patil, 2015)

\begin{tabular}{|l|l|}
\hline Biljni materijal/Plant material & Supstrati/substrates \\
\hline Korijen mrkve & $\begin{array}{l}\text { 2-meticikloheksanon, suspstituirani acetofenoni, aromatski, } \\
\text { heteroaromatski i alifatski ketoni, heteroarilni metilni ketoni }\end{array}$ \\
\hline Korijen kasave Manihot esculenta i Manihot dulcis & alifatski i aromatski aldehidi i ketoni \\
\hline Korijen Conium macalatum & benzaldehid \\
\hline Korijen mrkve i gorušice & $\beta$-ketoesteri \\
\hline Korijen korova & acetofenon \\
\hline $\begin{array}{l}\text { Gomolj krumpira jama, tara i korijen vlasca, korijandra, čič- } \\
\text { ka, đumbira, lotusa, rotkvice, manioke, arakake, cikle, repe i } \\
\text { jakona }\end{array}$ & derivati acetofenona \\
\hline Mrkva, krumpir, batat, jabuka, krastavac, čččak i luk & kamforkinoni \\
\hline Kora plodapasiflore & aromatski aldehidi i ketoni \\
\hline Jabuka, mrkva, krastavac, luk, krumpir, rotkvica, batat & supstituirani acetofenoni, $\beta$-ketoesteri \\
\hline $\begin{array}{l}\text { Jabuka, banana, naranča, krumpir, jagoda, poriluk, šlkiva, češ- } \\
\text { njak, luk, vušnja, jujube, jer. artičoka i grožđe }\end{array}$ & fluorenoni \\
\hline Kokosova voda & alifatski i aromatski aldehidi i ketoni \\
\hline Brokula, cvjetača, špinat & aromatski ketoni \\
\hline Jabuka, mrkva, krastavac, luk, krumpir, rotkvica, batat & acetofenoni \\
\hline Aloe vera & aromatski aldehidi \\
\hline Sjeme soje & aromatski aldehidi i ketoni \\
\hline Banana i kukuruz & benzaldehid \\
\hline Klementina & aromatski ketoni \\
\hline $\begin{array}{l}\text { Đumbir, jam, krumpir, ljute papričice, paprika, kupus, } \\
\text { krastavac, grah, korijander, poriluk i salata }\end{array}$ & aromatski i alifatski aldehidi i ketoni \\
\hline
\end{tabular}

Mrkva je u biokatalizi privukla veliku pažnju budući da njena upotreba ima mnoge prednosti: dokazane visoke stope konverzije i visoki stupanj enantioselektivnosti, nisu potrebni aseptični uvjeti rada niti puferirani mediji, reakcije se provode pri blagim uvjetima (voda kao otapalo i sobna temperatura), te posebice niska cijena mrkve i dostupnosti širom svijeta.To dokazuju i brojne znanstvene grupe iz Argentine, Brazila, Kine, Francuske, Indije, Italije, Japana, Latvije, Poljske, Južne Koreje, Švedske, Urugvaja koje se bave istraživanjem biokatalitičkog potencijala mrkve (Omori i sur., 2016).

Yadav i suradnici (2000) istraživali su upotrebu korijena mrkve za asimetričnu redukciju azidoketona, intermedijera u sintezi kiralnih $\beta$-amino aril etanola, farmaceutski vrlo važnih spojeva. Ključan korak tih reakcija je pretvorba azidoacetofenona u (R)-(-)-azidobenzil alkohol. U toj studiji veći su prinosi postignuti upotrebom mrkve kao biokatalizatora nego upotrebom pekarskog kvasca (ee vrijednosti $>99 \%$ i prinos izolacije 85-92\%). Nadalje, ista skupina istraživača istraživala je upotrebu korijena mrkve za enantioselektivne redukcije različitih alifatskih i aromatskih ketona i $\gamma$-ketoestera. Korišten je 41 različit supstrat te su ee vrijednosti bile za sve barem $90 \%$ s prinosima $50-82 \%$, s trajanjem pretvorbe $40-70 \mathrm{~h}$. Kod redukcije $2 \beta$-ketoestera došlo je do brže redukcije $(R)$-izomera nego $(S)$-izomera. Nadalje, veliku pažnju izazvala je kiralna redukcija nekoliko alifatskih ketona budući da je to kemijski zahtjevna reakcija. Prinosi su bili niski do srednji (32-50\%) s ee vrijednostima $71-92 \%$ dok je trajanje reakcije bilo nešto duže ( $80-102 \mathrm{~h})$ nego za druge supstrate (Yadav i sur., 2002). Comasseto i suradnici (2004) koristili su korijen mrkve u sintezi različitih organočalkogenih $\alpha$-metilbenzil alkohola. Do reakcije nije došlo susptitucijom selena na orto-položaju dok je supstitucijom sumpora na isti položaj postignut niski prinos. $U$ ostalim slučajevma, nakon $48-72 \mathrm{~h}$ prinos je bio $72-97 \% \mathrm{~s}$ ee vrijednostima $>99 \%$ za $(S)$-izomer. Andrade i suradnici (2006) proveli su studiju upotrebe 16 vrsta povrća (korijenja i gomolja) u redukciji različitih ketona te oksidaciji 3 derivata 1-feniletanola. Oksidacija 1-feniletanola s korijenom čička, repe, crvenog batata, jakona i đumbira nije rezultirala odgovarajućim ketonom. Međutim, upotreba đumbira je rezultirala prinosom $(S)$-alkohola s $>98 \%$ ee dok je jakon dao $99 \%(S)$-alkohola s $93 \%$ ee. Arakaka je postigla najveći prinos odgovarajućeg ketona $-88 \%$, s 12 $\%(S)$-alkohola. Zatim slijedi korijen rotkvice s prinosom ketona $74 \%, 26 \%(R)$-alkohola s $98 \%$ ee; korijen tara $(67 \%, 33 \%(R)$ alkohola s $41 \%$ ee) te lukovice vlasca ( $54 \%, 46 \%(R)$-alkohola s $>98 \%$ ee). Nadalje, reakcije oksidacije četiri različita supstrata provedene su pomoću 12 biljaka. Za supstrat racemičnu smjesu 1-(4-nitrofenil)-etanola, kao najbolji biokatalizator pokazao se 
gomolj jama. Lukovice vlasca, korijen korijandra i gomolj krumpira proveli su potpunu oksidaciju alkohola (96-100 \% prinosa). Uz oksidaciju alkohola 1-(4-nitrofenil)-etanola dodatno je došlo $\mathrm{i}$ do redukcije nitro grupe $\mathrm{u}$ amino. Tako je uz korijen arakake $\mathrm{i}$ korijen cikle dobiven prinos $4>$-aminoacetofenona od 86 i $92 \%$. Pomoću korijena cikle nitrobenzen je reduciran u anilin s prinosom od $52 \%$ nakon 8 dana, dok su korijen rotkvice i gomolj đumbira učinkovito proveli oksidaciju 1-(4-metilselenofenil)etanola u keton (Andrade i sur., 2006).

Sousa i suradnici (2006) istraživali su potencijal 6 vrsta povrća za redukciju acetofenona u kiralni fenil-etanol. Povrće koje su koristili bilo je: patlidžan (Solanum melongena L.) (prinos produkta 42,1\%), slatka kasava (Manihot dulcis (J.F. Gmel.) Pax) (85,5\%), kasava (Manihot esculenta) (89,3\%), mrkva (Daucus carota) $(46,3 \%)$, taro (Colocasia esculenta) $(55,8 \%)$, i slatki krumpir (Ipomoea batatas) $(42,6 \%)$. Rezultirajući visokim prinosom produkta dvije vrste kasave korištene su zatim u reakcijama redukcije acetofenona, benzaldehida, cinamaldehida i furfuraldehida pri sobnoj temperaturi tijekom 3 dana. Prinosi su bili u rasponu od 84 do $100 \%$ s ee vrijednosti $>94 \%$. Regioselektivnost je uočena u slučaju 2 derivata cinamaldehida gdje se odvila samo redukcija karbonilne skupine. Zatim su kasave korištene i za redukciju drugih supstrata: alifatskih, cikličkih i $\alpha, \beta$-nezasićenih ketona, te derivata karboksilnih kiselina i to $\beta$-ketoestera, nitrila i amida. Dobiveni su odlični prinosi s heksan-3-onom $(97,5 \%$; 96,7 \% za svaku vrstu kasave), ciklopentanonom (92,3\%; 93,4 \%) i cikloheksanonom (97,3\%; 91,7\%). Alkoholi $(S)$-konfiguracije dobiveni su s ee vrijednostima 93-98\%. Manji prinosi dobiveni su za pulegon i karvon, dok za dva steroidal-3-ona nije došlo do reakcije. Dominantna reakcija za transformaciju estera bila je hidroliza, dok je iz $\beta$-ketoestera korištenjem $M$. dulcis nastao (S)-etil-3-hidroksibutanoat s prinosom od $95,4 \%$ i ee $98 \%$. Benzamid i benzonitril ostali su netaknuti.

Sposobnost redukcije prokiralnih ketona ispitana je i za druge biljne vrste. Zeleni slanutak (Phaseolus aureus Roxb.) je povrće koje se koristi u Indiji za pripremu jela dal-a i curry-a. Dodatak acetofenona u namočeni zeleni slanutak tijekom 24 sata na temperaturi $10-15{ }^{\circ} \mathrm{C}$ rezultirao je $(S)$-1-feniletanolom s prinosom od $52 \%$ i $84 \%$ ee. Ovaj biokatalitički sustav primijenjen je na različite aromatske i alifatske ketone pri čemu su prinosi varirali od 23 do $55 \%$, a optička čistoća od 72 do 98 \% (Kumaraswamy i Ramesh, 2003). Nagaoka (2004) je primijenio drugi pristup biljnom materijalu kao biokatalizatoru. Naime, usitnjeni biljni materijal (prah) imobiliziran je u kuglice alginata. Biljke koje je koristio bile su mlado lišće pšenice, ječma, lišće Artemisia vulgaris L., morska trava, mrkva i bundeva te pšenične mekinje, jednostanične zelene alge i pekarski kvasac. Kao supstrat korištena je racemična smjesa 2-naftil1-etanola. Tako je supstrat pretvoren u $(R)$-izomer pomoću $A$. vulgaris, dok je pomoću lišća pšenice dobiven $(S)$-izomer. U oba slučaja prinos je bio $50 \%$ a ee $>99 \%$. Međutim, važno je napomenuti da ovakvi biokatalitički sustavi zahtjevaju prethodnu aktivaciju apoenzimima i kofaktorima.

Machado i suradnici (2008) po prvi puta su koristili koru ploda pasiflore (Passiflora edulisin) za bioredukciju derivata acetofenona, benzaldehida, furfuralaldehida i cinamaladehida. Produkti su dobiveni u dobrom prinosu, ali s niskim do srednjim enantiomernim viškom. Xie i suradnici (2009) istražili su potencijal svježeg voća i povrća kao što je jabuka (Malus pumila), banana (Musa balbisiana), naranča (Citrus reticulate), krumpir (Solanum tuberosum), jagoda (Fragaria ananassa), poriluk (Allium fistulosum), šljiva (Prunus spp.), češnjak (Allium sativum), luk (Allium cepa), višnja (Prunus pseudocerasus), jujube (Zizyphus jujube), jer. artičoka (Helianthus tuberosus) i grožđe (Vitis spp.) u enantioselektivnoj redukciji fluorenona (tablica 2). Između upotrijebljenog voća i povrća najbolji rezultati postignuti su upotrebom grožđa (pretvorba 97 \% i ee $99 \%$ ), dok je češnjak bio potpuno inaktivan. Apsolutna konfiguracija produkta u svim slučajevima je bila $R$.

Tablica 2. Enantioselektivna redukcija 2-klorofluorenona katalizirana različitim voćem i povrćem (Xie i sur., 2009)

Table 2. Enantiselective reduction of 2-chlorofluorenone catalysed by different fruits and vegetables (Xie et al., 2009)

\begin{tabular}{|c|c|c|}
\hline Biljka/Plant & $\begin{array}{c}\text { Pretvorba/ } \\
\text { Conversi- } \\
\text { on(\%) }\end{array}$ & $\begin{array}{l}\text { ee/ee } \\
(\%)\end{array}$ \\
\hline Jabuka (Malus pumila Mill.) & 69 & 90 \\
\hline $\begin{array}{l}\text { Banana (Musa balbisiana } \\
\text { Colla) }\end{array}$ & 30 & 46 \\
\hline $\begin{array}{l}\text { Naranča (Citrus reticulata } \\
\text { Blanco.) }\end{array}$ & 15 & 43 \\
\hline $\begin{array}{l}\text { Krumpir (Solanum } \\
\text { tuberosum L.) }\end{array}$ & 7 & 50 \\
\hline $\begin{array}{l}\text { Jagoda (Fragaria ananassa } \\
\text { Duch.) }\end{array}$ & 37 & 93 \\
\hline $\begin{array}{l}\text { Poriluk (Allium fistulosum L. } \\
\text { var.) }\end{array}$ & 13 & 72 \\
\hline Šljiva (Prunus spp.) & 100 & 50 \\
\hline Češnjak (Allium saticum L.) & - & - \\
\hline Luk (Allium cepa L) & 8 & 26 \\
\hline $\begin{array}{l}\text { Višnja (Prunus } \\
\text { pseudocerasus) }\end{array}$ & 4 & 87 \\
\hline $\begin{array}{l}\text { Jujube (Zizyphus jujube } \\
\text { Mill.) }\end{array}$ & 88 & 28 \\
\hline $\begin{array}{l}\text { Jer. artičoka (Helianthus } \\
\text { tuberosus) }\end{array}$ & 100 & 76 \\
\hline Grožđe (Vitis spp.) & 97 & 99 \\
\hline
\end{tabular}

Fonseca i suradnici (2009) koristili su kokosov sok (Cocos nucifera) za redukciju niza alifatskih i aromatskih aldehida i ketona. Sok kokosa pokazao je vrlo učinkovitu, regio- i enantioselektivnu redukciju aromatskih i alifatskih spojeva s karbonilnim skupinama. 1-feniletanol je nastao iz acetofenona $\mathrm{s}$ prinosom od $79 \%$ kao jedinstveni enantiomer $S$ konfiguracije, u skladu s Prelogovim pravilom, te s ee od $95 \%$. Učinkovita redukcija aromatskih aldehida i tri ketona u njihove odgovarajuće alkohole s umjerenim do odličnim kemijskim prinosom postignuta je upotrebom homogenata brokule (B. oleracea var. 
italic), cvjetače (B. oleracea var. Botrytis), cikle (B. vulgaris var. cicla) i špinata (S. oleraceae) u vodenoj suspenziji uz blage reakcijske uvjete. Upotreba brokule i cvjetače rezultirala je maksimalnim prinosom biokonverzije u kratkom vremenu. Ispitivanje povrća pokazalo je izvrstan prinos (>99\%) nakon 24 sata za aromatske aldehide (Suárez-Franco i sur., 2010).

Fruchey (2011) je proučavao biokatalitičku aktivnost sjemenki nekoliko vrsta graška (Cajanu scajan, Phaseolus vulgaris, Cicer arietinum, Pisum sativum, Vigna unguiculata) u redukciji nekoliko ketona, 4'-kloroacetofenona, 4'-metoksiacetofenona, 4-fenil-2-butanona, 2-oktanona, 1-indanona. Iako su sve vrste graška osigurale visoke ee vrijednosti (70-99 \%) neke vrste su se pokazale boljim bikatalizatorom ovisno o upotrebljenom supstratu. Stereokemija produkta strogo je bila vezana uz vrstu graška dok je upotreba fosfatnog pufera kao reakcijskog medija povećala stupanj pretvorbe. Upotreba fosfatnog pufera osigurala je optimalni $\mathrm{pH}$ 5,5-7,5 za katalitičku aktivnost enzimskog sustava graška.

Phukan i Devi (2012) proveli su redukciju aldehida i ketona pomoću ploda rajčice (Lycopersicum esculentum) namočenog u deioniziranu vodu s visokom enantioselektivnošću (92-99 \%) i prinosom $(70-95 \%)$. U usporedbi s radom Yadav i suradnika (2009) reakcija je trajala kraće te je provedena unutar 25-35 h. Nadalje, Omori i suradnici (2016) istražili su potencijal 13 vrsta voća: indijskog oraščića (Anacardium occidental), karambole (Averrhoa carambola), jagode (Fragaria spp.), šećerne jabuke (Annona squamosa), kivija (Actinidia deliciosa), smokve (Ficus carica), avokada (Persea americana), šipka (Punica granatum), mušmule (Eriobotrya japonica), brazilske trešnje (Eugnia uniflora), šljive (Prunus domestica), kruške (Pyrus sp.), tamarila (Solanum betaceum) i korijenja 5 biljaka: peršina (Petroselinum crispum), đumbira (Zingiber officinale), komorača (Foeniculum vulgare), korijandra (Coriandrum sativum) i narančaste mrkve (Daucus carota ssp. sativus var. sativus) prisutnog na lokalnom tržištu kao biokatalizatora za redukciju modelnog spoja (acetofenon). No, redukcijsku aktivnost pokazali su samo đumbir, komorač i narančasta mrkva kao najbolji biokatalizator. Nada- lje, različite vrste mrkve (narančasta, žuta i ljubičasta mrkva) u dodiru s supstituiranim acetofenonima dale su odgovarajuće optički aktivne alkohole $\mathrm{u}$ dobrim do odličnim prinosima s visokom enantioselektivnošću. Usporedno, ljubičasta mrkva ( $D a$ ucus carota ssp. sativus var. atrorubens) pokazala je najbolje rezultate s većinom ispitivanih acetofenona, u smislu prinosa $\mathrm{i}$ enantiomernog viška.

Pavoković i suradnici (2017) istražili su asimetričnu bioredukciju 1-(3,4-dimetilfenil)etanona u 1-(3,4-dimetilfenil) etanol u vodenom mediju pomoću korijenja devet vrsta povrća. Povrće odabrano na temelju cjelogodišnje dostupnosti i niske cijene je mrkva, cikla, crna i bijela rotkvica, celer, hren, peršin i šećerna repa. Najbolji prinosi postignuti su upotrebom bijele rotkvice, mrkve i šećerne repe $(67,65,71,33$ i 70,59 \%) $\mathrm{s}$ enantiomernim viškom $>95 \%$. Upotreba hrena i peršina kao biokatalizatora rezultirala je nastankom racemične smjese produkta. Radi usporedbe enantioselektivnosti, izvedena je redukcija pomoću natrijeva tetrahidroborata klasičnom organskom sintezom u etanolu koja je rezultirala prinosom od $44 \%$ i racemičnom smjesom produkta.

Kiralni heteroarilni alkoholi su važni intermedijeri u sintezi biološki aktivnih molekula. U literaturi postoje brojni radovi koji opisuju njihovu sintezu upotrebom biokatalizatora izoliranih iz mikroorganizama ili različitih biljnih tkiva. No, komercijalna upotreba takvih biokatalitičkih sustava ima ograničenja: trajanje reakcije, niska koncentracija supstrata u hranjivoj podlozi, niski prinosi produkata nakon izolacije i loša enantioselektivnost. Lakshmi i suradnici (2011) proučavali su kiralnu redukciju supstituiranih heteroarilnih prokiralnih ketona upotrebom mrkve kao biokatalizatora. Pokazali su da dehidrogenaze prisutne u mrkvi selektivno reduciraju supstituirane aromatske heterocikličke metil ketone u odgovarajuće kiralne sekundarne alkohole s dobrim prinosom (60-95\%) i visokom enantioselektivnosti (76-99 $\%$ ). Bioredukcija različitih heteroaril-metil-ketona (piridinskih i pirolnih) u odgovarajuće kiralne alkohole rezultirala je isključivo $S$ konfiguracijom dok je bioredukcija furana i tiofenskih derivata rezultirala $R$ konfiguracijom produkta (tablica 3 ).

Tablica 3. Asimetrična redukcija supstituiranih heteroarilnih ketona pomoću mrkve (Lakshmi i sur., 2011)

Table 3. Asymetric reduction of substituted heteroaryl ketones by carrot (Lakshmi et al., 2011)

\begin{tabular}{|l|c|c|c|c|c|}
\hline Produkt/Product & $\begin{array}{c}\text { Vrijeme/ } \\
\text { Time (h) }\end{array}$ & $\begin{array}{c}\text { Pretvorba/ } \\
\text { Conversion } \\
(\%)\end{array}$ & Prinos/Yield (\%) & $\begin{array}{c}\text { ee/ } \\
\text { ee(\%) }\end{array}$ & $\begin{array}{c}\text { Apsolutna } \\
\text { konfiguracija/Apso-lute } \\
\text { configuration }\end{array}$ \\
\hline 2-(1-hidroksietil)piridin & 48 & 100 & 95 & 99 & $S$ \\
\hline 3-(1- hidroksietil)piridin & 56 & 90 & 94 & 98 & $S$ \\
\hline 4-(1- hidroksietil)piridin & 52 & 100 & 94 & 92 & $S$ \\
\hline 2-(1- hidroksietil)-6-kloro-piridin & 60 & 80 & 74 & 89 & $S$ \\
\hline 2-(1- hidroksietil)-6-bromo-piridin & 65 & 75 & 78 & 92 & $S$ \\
\hline 2-(1- hidroksietil)-4-metil-piridin & 55 & 95 & 80 & 96 & $S$ \\
\hline 2-(1-hidroksipropil)piridin & 65 & 95 & 63 & 90 & $S$ \\
\hline 2-(1- hidroksietil)pirol & 72 & 65 & 65 & 90 & $S$ \\
\hline 2-(1- hidroksietil)furan & 76 & 55 & 60 & 76 & $R$ \\
\hline 2-(1- hidroksietil)tiofen & 70 & 50 & 55 & 7 & $R$ \\
\hline
\end{tabular}

Kao što je već navedeno, uobičajeni problem kod korištenja biljaka kao biokatalizatora je mikrobna kontaminacija. Tako su Javidnia i suradnici (2013) proučavali ulogu endofit- nih mikroorganizama u asimetričnoj redukciji osam prokiralnih ketoestera pomoću korijena mrkve i gorušice. Uočili su da je u nesterilnim uvjetima gorušica pokazala bolju biokatalitič- 
ku aktivnost. Međutim, u sterilnim uvjetima mrkva je pokazala bolje prinose nego gorušica. Rezultati te studije podupiru tvrdnju da su epifitni mikroorganizmi uključeni u biotransformacije. Da bi se izbjegla mikrobna kontaminacija i utjecaj endofitne mikroflore površinska sterilizacija biljnog materijala je ključan korak u pripremi reakcijskog sustava.

\section{Esterazna aktivnost voća i povrća}

Esterazna aktivnost proučavana je za brojne biljne vrste, neke u kulturi biljnih stanica a neke u svježim dijelovima biljke, uključujući Nicotiana tabacum (Suga, 1986), pulpu krumpira (Solanum tuberosum cv. Saturna) i gomolje jeruzalemske artičoke (Helianthus tuberosus Jacq.) (Mironowicz, 1998),suspenzijsku kulturu Spirodela punctata, Nephrolepis exaltata L., Cyrtomium falcatum, Nephrolepis cordifolia, Helianthus tuberosus, Daucus carota i Petunia hybrida Vilm. (Mironowicz i sur., 1994) te pulpu jabuka (Malus sylvestris Mill.) (Mironowicz i sur., 1995). Naribani gomolji jeruzalemske artičoke bili su učinkovitiji nego suspenzijska kultura za brojne supstrate. Suga i suradnici još su 1986. godine utvrdili da kultivirane stanice $N$. tabacum imaju sposobnost razlikovanja $(+)$ i (-)-bornil acetata i odgovarajućih izobornil i izopinokamfenil acetata, a prednost je dana $(R)$-enantiomeru. Tako je iz $(+)$-bornil acetata hidrolizom i oksidacijom nastao kamfor, dok za (-)-bornil acetat to nije bio slučaj. Intermedijer tih reakcija, alkohol (+)-borneol dosegao je maksimalnu koncentraciju nakon 4 dana, ali prinos kamfora nije bio veći od $25 \%$. Slijedeći te studije, Mironowicz (1998) je pokazao da gomolji krumpira (Solanum tuberosum) i pulpa jeruzalemske artičoke imaju različitu brzinu hidrolize racemične smjese kiralnih estera te da se nastali alkoholi polako prevode u ketone. Usporedba hidrolize serija alifatskih i aromatskih acetata i metil estera pomoću prethodno navedenih biljaka pokazala je različite brzine hidrolize. Na primjer, benzil acetat je potpuno hidroliziran pomoću Spirodela punctata, Nephrolepis exaltata, Cyrtomium falcatum i Nephrolepis cordifolia dok je Petunia hybrida hidrolizirala samo $8 \%$ supstrata. H. tuberosus se pokazao kao najmanje učinkovit biokatalizator u toj reakciji. Uočena je selektivnost u hidrolizi racemičnih smjesa estera s $S$. punctata (Pawlowicz i Siewinski, 1987), Dendrobium phalaenopsis i Daucus caro$t a$, ne rezultirajući uvijek istim enantiomerom. Nadalje, Mironowicz i suradnici (1995) je koristio pulpu dviju vrsta jabuka (Malus sylvestris), „Golden“ i „Gloucester“, u enantiospecifičnoj hidrolizi racemične smjese acetata. Pulpa jabuke pomiješana je s malom količinom supstrata te je takva smjesa miješana $u$ fosfatnom puferu tijekom 2 dana. Produkti hidrolize su također oksidirani u ketone u malom prinosu. Primjer je hidroliza/oksidacija racemata 1-feniletil acetata u $(S)$-alkohol s prinosom od $40 \%$ te s $15 \%$ ketona acetofenona; $26 \%(R)$ supstrata je ostalo nepromijenjeno (Mironowicz, 1997). Iste reakcije provedene su s izdancima jabuke (stablo) i transformiranim (Agrobacterium rhizogenes) korijenjem mrkve i jabuke. Izdanci stabla jabuke preveli su racemat 1 -feniletil acetata $\mathrm{u}$ (S)-alkohol s prinosom od $98 \%$ nakon 5 dana. Transformirani korijen jabuke dao je $95 \%$ prinosa produkta ali s vrlo malim ee, dok je tranformirana i netranformirana mrkva provela vrlo slabu pretvorbu 4 različita supstrata u alkohole ili ketone (Mironowicz i Kromer, 1998). Enantioselektivna hidroliza racemata 1-feniletil i 1-naftiletil acetata i redukcija metilfenil i naftil ketona provedena je pomoću korijena mrkve, celera i hrena (Maczka i Mironowicz, 2002). Hidroliza, oksidacija i redukcija racemata 1-feniletil acetata pomoću enzimskog sustava celera rezultirala je prvo stvaranjem $(S)$-alkohola koji je oksidiran $\mathrm{u}$ acetofenon dok je $(R)$-alkohol ostao nepromijenjen. Nasuprot tome, enzimski sustav hrena je bio znatno sporiji te ni nakon 48 sati nije mogao potpuno oksidirati intermedijerni $(S)$-alkohol te je $(R)$-alkohol ostao u $66 \%$ ee. Usitnjeni korijen mrkve i celera upotrijebljeni su za enantioselektivnu redukciju šest bromo- i metoksiacetofenon derivata tijekom 48 sati na sobnoj temperaturi i pH 6,5 i 6,2. Oba biokatalitička sustava su reducirala 3-metoksi acetofenon u (S)-(-)-(3-metoksifenil) etanol s visokim prinosom i $98-100 \%$ ee. Bromo derivati su brže bili reducirani nego metoksiacetofenoni (Maczka i Mironowicz, 2004).

Ostaci industrijske prerade citrusa, kao što su sjemenke, kora i pulpa, čine oko 50 \% voća i potencijalni su izvor vrijednih fitokemikalija i enzima (Dahmoune i sur., 2013; Hayat i sur., 2009). Prisutnost enzima acetil esteraze (EA) uočena je u svim dijelovima citrusnog voća (Citrus sinensis, C. paradisi, C. limon, C. reticulata, C. aurantifolia) (Nielsen i Christensen, 2002). Ovaj enzim osim što katalizira reakcije hidrolize, ovisno o reakcijskim uvjetima, također katalizira i reakcije esterifikacije i transesterifikacije. Tako su Da Silva i suradnici (2017) istražili potencijal kore naranče (Citrus aurantium), limuna (Citrus limonum) i mandarine (Citrus reticulate) kao biokatalizatora za enantioselektivne reakcije esterifikacije, s ciljem dobivanja racemičnih sekundarnih alkohola. Rezultati studije su pokazali da upotreba kore naranče (Citrus aurantium) i limuna u katalitičkoj esterifikaciji racemičnih alkohola daje dobru konverziju (75,7 i 67,4 \%) s odličnim ee (73 i $95 \%$ $R$-izomera) te da je praktična za proizvodnju kiralnih estera $\mathrm{i}$ alkohola. Nasuprot tome, biokatalitička aktivnost kore mandarine rezultirala je srednjom konverzijom $(52,9 \%)$ i niskim ee (6\% $\%$-izomera).

\section{Zaključci}

U svijetu se otprilike u prehrambenoj industriji i poljoprivredi koristi 7000 biljnih vrsta. Brojne se biljne vrste koriste također kao arome, u kozmetičkoj industriji, farmaceutskoj insustriji, kao građevni materijal, itd. No, potencijal upotrebe biljaka daleko je veći. Istraživanja potencijala lokalno dostupnog povrća, voća, biljaka i biljnog otpada kao biokatalitičkog sustava za standardne organske kemijske reakcije može biti od velikog ekonomskog značaja. Upotreba dijelova biljaka kao biokatalizatora ima mnoge prednosti u odnosu na standardne kemijske reagense, kulturu biljnih stanica ili izolirane enzime. Na primjer, takvi biokatalitički sustavi ne zahtjevaju dodatak skupih kofaktora budući da su oni već prisutni u biljnom tkivu. Ovisno o upotrebljenoj biljnoj vrsti i dijelu biljke jedan od enantiomera se može dobiti u visokom prinosu i s visokom enantiomernom čistoćom, što je kritičan faktor za razvoj lijekova i ostalih biološki aktivnih spojeva. Nadalje, s ekonomičnog gledišta značajna je ušteda vremena, niži su troškovi, a priprema takvog reakcijskog sustava je jednostavna te se može koristiti više puta. Takvi sustavi su sposobni provoditi i temeljne pretvorbe ksenobiotičkih supstrata. Nedostaci su ne- 
što složeniji postupci izolacije produkta, istovremeno se mogu odvijati drugi enzimski procesi te problem botaničke identifikacije (vrste ili kultivara) pojedine biljke. No, prednosti bi trebale nadvladati nedostatke, posebice jer takvi biokatalitički sustavi pružaju mogućnost upotrebe prirodnih produkata kao održivih kemijskih reagensa u farmaceutskoj industriji i poljoprivredi umjesto skupih i ekološki neprihvatljivih reagensa što je u skladu sa zelenom kemijom. Provedene studije upotrebe povrća kao biokatalizatora kao i daljnja istraživanja njihovog potencijala, otvaraju vrata novom području sintetske organske kemije. Primjena biljnih biokatalitičkih sustava predstavlja značajnu alternativu sintetskim kemijskim transformacijama kojom bi industrija zadovoljila ne samo ekološke zahtjeve već i one ekonomske.

\section{Literatura}

Andrade L.H., Utsunomiya R.S., Omori A.T., Porto A.L.M., Comasseto J.V. (2006) Edible catalysts for clean chemical reactions: Bioreduction of aromatic ketones and biooxidation of secondary alcohols using plants. Journal of Molecular Catalysis B: Enzymatic, 38 84-90.

Baldassarre F., Bertoni G., Chiappe C., Marioni F. (2000) Preparative synthesis of chiral alcohols by enantioselective reduction with Daucus carota root as biocatalyst. Journal of Molecular Catalysis B: Enzymatic, 1 55-58.

Bruni R., Fantin G., Medici A., Pedrini P., Sacchetti G. (2002) Plants in organic synthesis: an alternative to baker's yeast. Tetrahedron Letters, 43 3377-3379.

Camacho-Muñoz D., Petrie B., Castrignanò E., Kasprzyk-Hordern B. (2016) Enantiomeric profilling of chiral pharmacologically active compounds in the environment with the usage of chiral liquid chromatography coupled with tandem mass spectrometry. Current Analytical Chemistry, 12 303-314.

Chang X., Yang Z., Zeng R., Yang G., Yan J. (2010) Production ofChiral Aromatic Alcohol by Asymmetric Reduction with Vegetable Catalyst. Chinese Journal of Chemical Engineering, 18 (6) 1029-1033.

Chin-Joe I., Nelisse P.M., Straathof A.J.J., Jongejan J.A., Pronk J.T., Heijnen J.J. (2000) Hydrolytic activity in baker's yeast limits the yield of asymmetric 3-oxo ester reduction. $\mathrm{Bi}$ otechnology and Bioengineering, 69 370-376.

Comasseto J.V., Omori A.T., Porto A.L.M., Andrade L.H. (2004) Preparation of chiral organochalcogeno- $\alpha$-methylbenzyl alcohols via biocatalysis. The role of Daucus carota root. Tetrahedron Letters, 45 473-476.

Da Silva F.F.M., Ferreira D.A., Monte F.J.Q., Gomes de Lemos T.L. (2017) Synthesis of chiral esters and alcohols via enantioselectiveesterification with Citrus aurantium peels as biocatalyst. Industrial Crops and Products, 96 23-29.

Dahmoune F., Boulekbache L., Moussi K., Aoun O., Spigno G., Madani K. (2013) Valorization of Citrus limon residues for the recovery of antioxidants: Evaluation and optimization of microwave and ultrasoundapplicationto solvent extraction. Industrial Crops and Products, 50 77-87.

Faber K. (ed) (2004) Biotransformations in organic chemistry: a textbook. Springer-Verlag, Berlin, Germany.
Fardelone L.C., Augusto J., Rodrigues R., Moran P.J.S. (2004) Baker's yeast-mediated asymmetric reduction of cinnamaldehyde derivatives. Journal of Molecular Catalysis B: Enzymatic, 29 41-45.

Fonseca A.M., Monte F.J.Q., de Oliveira M.C.F., de Mattosa M.C., Cordell G.A., Braz-Filho R., Lemos T.L.G. (2009) Coconut water (Cocos nucifera L.) - A new biocatalyst systemfor organic synthesis. Journal of Molecular Catalysis B: Enzymatic, 57 78-82.

Fruchey E.R. (2011) Asymmetric reductions of ketones, imines, and oximes using biocatalytic enzymes found in pea plants, Honors Research Thesis, The Ohio State University, http://hdl.handle.net/1811/48915.

Hayat K., Hussain S., Abbas S., Farooq U., Ding B., Xia S., Jia C., Zhang X., Xia W. (2009) Optimized microwave-assisted extraction of phenolic acids from cit-rusmandarin peels and evaluation of antioxidant activity in vitro. Separation and Purification Technology, 70 63-70.

Javidnia K., Faghih Mirzaei E., Rezazadeh S.R., Attarroshan M., Gholami M., Miri R. (2013) Stereoselective reduction of some $\beta$-ketoesters by Brassica rapa and Daucus carota using plant roots and plant cultured cells. International Journal of ChemTech Research, 5 (4) 1744-1749.

Javidnia K., Faghih-Mirzaei E., Miri R., Attarroshan M., Zomorodian K. (2016) Stereoselective Reduction of Prochiral Ketones by Plant and Microbial Biocatalysts. Indian Journal of Pharmaceutical Sciences, 78 73-79.

Khor G.K., Uzir M.H. (2011) Saccharomyces cerevisiae: a potential stereospecific reduction tool for biotransformation of monoand sesquiterpenoids. Yeast, 28 93-107.

Kumaraswamy G., Ramesh S. (2003) Soaked Phaseolus aureus L: an efficient biocatalyst for asymmetric reduction of prochiral aromatic ketones. Green Chemistry, 5 306-308.

Lakshmi C.S., Reddy G.R., Rao A.B. (2011) Asymmetric Reduction of Heteroaryl Methyl Ketones Using Daucus carota. Green and Sustainable Chemistry, 1 117-122.

Machado L.L., Monte F.J.Q., de Oliveira M.C.F., de Mattos M.C., Lemos T.L.G., Fernández V.G., de Gonzalo G., Gotor V. (2008) Bioreduction of aromatic aldehydes and ketones by fruits' barks ofPassiflora edulis. Journal of Molecular Catalysis B: Enzymatic, 54 130-133.

Maczka W. K., Mironowicz A. (2004) Enantioselective reduction of bromo- and methoxyacetophenone derivatives using carrot and celeriac enzymatic system. Tetrahedron: Asymmetry, 15 1965-1967.

Mączka W.K., Mironowicz A. (2002) Enantioselective hydrolysis of 1-aryl ethyl acetates and reduction of aryl methyl ketones using carrot, celeriac and horseradish enzyme systems. Tetrahedron: Asymmetry, 13 2299-2302.

Matsuda T., Yamanaka R., Nakamura K. (2009) Recent progress in biocatalysisfor asymmetric oxidation and reduction. Tetrahedron: Asymmetry, 20 513-557.

Mironowicz A.(1997) Apples as enantiospecific bioreagents in the hydrolysis of racemic esters and oxygenation of alcohols obtained during the process. Acta Societatis Botanicorum Poloniae, 66 325-328.

Mironowicz A.(1998) Biotransformations of racemic acetates by potato and topinambur tubers. Phytochemistry, 47 1531-1534. 
Mironowicz A., Jarosz B., Siewinski A. (1995) The ability of fruit and vegetable enzyme system to hydrolyse ester bonds. Acta Societatis Botanicorum Poloniae, 64 281-285.

Mironowicz A., Kromer K. (1998) Apple-tree shoots and transformed carrot and apple roots used as biocatalysts in enantioselective acetate hydrolysis, alcohol oxidation and ketone reduction. Collection of Czechoslovak Chemical Communications, 63 1655-1662.

Mironowicz A., Kromer K., Pawlowicz P., Siewinski A. (1994) Abilities of some higher plants to hydrolyse the acetates of phenols and aromatic-aliphatic alcohols. Acta Societatis Botanicorum Poloniae, 63 43- 48.

Nagaoka H. (2004) Ability of different biomaterials to enantioselectively catalyze oxidation and reduction reactions. Biotechnology Progress, 20 128-133.

Nevoigt E. (2008) Progress in metabolic engineering of Saccharomyces cerevisiae. Microbiology and Molecular Biology Reviews, 72 379-412.

Nielsen J.E., Christensen T.M.I.E. (2002) Distribution of pectin methyl esterase and acetylesterase in the genus Citrus visualized by tissue prints and chromatography. Plant Science, $162799-807$.

Omori A. T., Lobo F. G., Do Amaral A. C. G., De Souza De Oliveira C. (2016) Purple carrots: Better biocatalysts for the enantioselective reduction of acetophenones than common orange carrots (D. carota). Journal of Molecular Catalysis B: Enzymatic, 127 93-97.

Patil D. (2015) Biocatalysis using plant material: A green access to asymmetric reduction. International Journal of ChemTech Research, 8 318-324.

Pavoković D., Buđa R., Andrašec F., Roje M., Cvjetko Bubalo M., Radojčić Redovniković I. (2017) Plant-mediated asymmetric reduction of 1-(3,4-dimethylphenyl) Ethanone. Tetrahedron: Asymmetry, 28 730-733.

Pawlowicz P., Siewinski A. (1987) Enantio- selective hydrolysis of esters and the oxidation of aromatic-aliphatic alcohols obtained therefrom by Spirodela oligorrhiza. Phytochemistry, 26 1001-1004.

Phukan K., Devi N. (2012) Biocatalytic preparative method of asymmetric alcohols using Lycopersicum esculentum (tomato). International Journal of ChemTech Research, 4(1) 203-207.

Reinhard E., Alfermann A. W. (1980) Biotransformation by plant cell cultures. Advances in Biochemical Engineering, 16 49-83.

Rodrigues J.A.R., Moran P.J.S., Conceição G.J.A., Fardelone L.C. (2004) Recent advances in the biocatalytic asymmetric reduction of acetophenone and $\alpha, \beta$-unsaturated carbonyl compounds. Food Technology and Biotechnology, 42 (4) 295-303.

Rodríguez P., Barton M., Aldabalde V., Onetto S., Panizza P., Menéndez P., Gonzalez D., Rodríguez S. (2007) Are endophytic microorganisms involved in the stereoselective reduction of ketones by Daucus carota root? Journal of Molecular Catalysis B: Enzymatic, 49 8-11.

Rouf A., Taneja S. C. (2014) synthesis of singleenantiomer bioactive molecules: a brief overview. Chirality, 26 63-78.

Santaniello E., Ferraboschi P., Manzocchi A. (2000) Recent advances on bioreductions mediated by baker's yeast and other microorganisms. U: Zwanenburg B., Mikoajczyk M., Kiełbasinski P. (ed): Enzymes in Action: Green Solutions for Chemical Problems, str. 95-115. Kluwer Academic, Dordrecht, Nizozemska.

Schmid A., Dordick J.S., Hauer B., Kiener A., Wubbolts M., Witholt B. (2001) Industrial biocatalysis today and tomorrow. Nature, 409 258-268.

Sousa J. S. N., Machado L. L., de Mattos M. C., Solange S., Lemos T. L. G., Cordell G. A. (2006) Bioreduction of aromatic aldehydes and ketones using Manihot species. Phytochemistry, 67 1637- 1643.

Suárez-Franco G., Hernández-Quiroz T., Navarro-Ocaña A., Oliart-Ros R.M., Valerio-Alfaro G. (2010) Plants as Green Alternative for Alcohol Preparation from Aromatic Aldehydes. Biotechnology and Bioprocess Engineering, 15 441-445.

Suga T., Hirata T., Izumi S. (1986) Enantioselectivity in the hydrolysis of bicyclic monoterpene acetates with the cultured cells of Nicotiana tabacum. Phytochemistry, 25 27912792.

Wandrey C., Liese A., Kihumbu D. (2000) Industrial Biocatalysis: past, present and future. Organic Process Research \& Development, 4 286-290.

Xie B., Yang J., Yang Q., Yuan W. (2009) Enantioselective reduction of fluorenones in surfactant-aqueous solution by fruits and vegetables. Journal of Molecular Catalysis B: Enzymatic, 61 284-288.

Yadav J.S., Thirupathi Reddy P., Nanda S., Bhaskar Rao A. (2000) Stereoselective synthesis of $(R)-(-)$-denopamine, $(R)$-(-)-tembamide and $(R)-(-)$-aegeline via asymmetric reduction of azidoketones by Daucus carota in aqueous medium. Tetrahedrom Asymmetry, 3381-3385.

Yadav J.S., Nanda S., Thirupathi Reddy, P., Bhaskar Rao, A. (2002) Efficient enantioselectivity reduction of ketones with Daucus carota root. Journal of Organic Chemistry, 67 39003903.

Yadav J.S., Subba Reddy B.V., Sreelakshmi C., Bhaskar Rao A. (2009) Enantioselective reduction of prochiral ketones employing sprouted Pisum sativa as biocatalyst. Synthesis, 11 1881-1885.

Yang Z.H., Zeng R., Yang G., Wang Y., Li L.Z., Lv Z.S., Yao M., LaiB. (2008) Assymetric reduction of prochiral ketones to chiral alcohols catalyzed by plants tissue. Journal of Industrial Microbiology and Biotechnology, 35 1047-1051. 